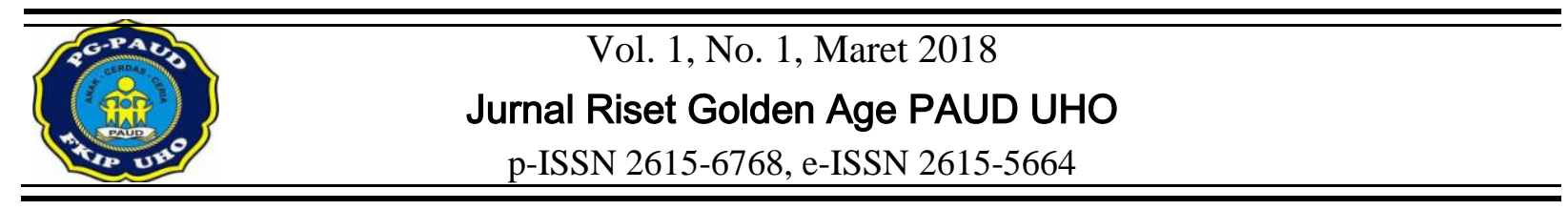

\title{
MENINGKATKAN MINAT MEMBACA ANAK MELALUI MEDIA KARTU KATA DENGAN TEMA BINATANG DI TAMAN KANAK-KANAK WUA-WUA KOTA KENDARI
}

\author{
Findriani $^{1)}$, Bambang Sugianto ${ }^{2)}$ \\ ${ }^{1}$ Alumni Jurusan PG-PAUD, Universitas Halu Oleo. Jln. H.E.A Mokodompit, Kendari 93232, \\ Indonesia. \\ ${ }^{2}$ Dosen Jurusan PG-PAUD, Universitas Halu Oleo. Jln. H.E.A Mokodompit, Kendari 93232, \\ Indonesia.
}

\begin{abstract}
Abstrak
Penelitian ini bertujuan untuk meningkatkan minat membaca anak melalui media kartu kata pada kelompok B Taman Kanak-kanak Wua-wua Kendari. Subjek dalam penelitian ini adalah guru dan anak yang berjumlah 17 orang. Jenis penelitian ini adalah Penelitian Tindakan Kelas yang dilakukan dalam dua siklus. Sebelum tindakan diperoleh presentase sebesar $35.3 \%$ dan mengalami peningkatan pada siklus I yaitu sebesar $64.7 \%$, dimana terdapat 8 anak yang mendapat nilai Berkembang Sesuai Harapan (***) dan 3 anak yang memperoleh nilai Berkembang Sangat Baik (****). Pada siklus II diperoleh presentase sebesar $88.2 \%$ yaitu 5 anak yang mendapat Berkembang Sesuai Harapan (***) dan 10 anak mendapat nilai Berkembang Sangat Baik (****). Dengan demikian dapat disimpulkan bahwa minat membaca anak pada kelompok B Taman Kanak-kanak Darul Fallah Wua-wua Kendari dapat ditingkatkan melalui media kartu kata.
\end{abstract}

Kata kunci: Minat, Membaca, Kartu Kata.

\section{THE INCREASED OF CHILDREN'S INTEREST IN READING THROUGH THE MEDIUM OF WORD CARDS WITH THE THEME OF ANIMALS IN GROUP B KINDERGARTEN WUA-WUA KENDARI}

\begin{abstract}
This study aims to increase children's interest in reading through the medium of word cards with the theme of animals in group B Kindergarten Wua-Wua Kendari. Subjects in this study were teachers and children totaling 17 people. This type of research is a classroom action research was conducted in two cycles. Before the action obtained a percentage of $35.3 \%$ and an increase in the first cycle is equal to 64.7\%, of which there are 8 children who scored Developing Appropriate Expectations (***) and 3 children whose grades Growing Very Good (****). In the second cycle a percentage of $88.2 \%$ was obtained in classical completeness is 5 children who received Developing Appropriate Expectations (***) and 10 children scored Growing Very Good (****). It can be concluded that the child's interest in reading in group B Preschool Darul Fallah Wua-Wua Kendari can be enhanced through the medium of said card.
\end{abstract}

Keywords: Interest, Reading, Word Cards.

\section{PENDAHULUAN}

Pendidikan adalah proses pembelajaran anak yang mengalami perubahan dan peningkatan. Anak yang tadinya tidak tahu menjadi tahu, tidak mengerti menjadi mengerti, tidak bisa menjadi bisa. Berkembangnya seorang anak akan ditandai seperti yang tadinya penakut menjadi berani, cengeng menjadi mandiri, peragu menjadi percaya diri. Tetapi tentu saja perubahan dan perkembangan anakanak itu tidak bisa disamaratakan karena setiap anak adalah unik dalam arti setiap anak berbeda keadaan jasmani-rohaninya dan berbeda pula tingkat perkembangannya. 
Bentuk pendidikan salah satunya adalah Pendidikan Anak Usia Dini. Pendidikan anak usia dini (PAUD) saat ini telah banyak diselenggarakan oleh masyarakat. Hal ini menunjukkan bahwa masyarakat sekarang mulai sadar pentingnya pendidikan anak usia dini. Pengembangan sumber daya manusia lebih mudah ketika dilakukan sejak usia dini. Anak merupakan generasi penerus bangsa dan keluarga. Anak merupakan investasi bangsa dan keluarga maka negara-negara maju memiliki keseriusan untuk mengembangkan PAUD yang lebih baik lagi.

Pendidikan anak usia dini merupakan usaha sadar untuk menfasilitasi pertumbuhan, keterampilan jasmani dan rohani anak, mengembangkan kepribadian yang dilakukan melalui upaya penyediaan pengalaman, pemberian rangsangan yang kaya dan bersifat menyeimbangkan yang bertujuan untuk mengembangkan kemampuan anak khususnya kemampuan kognitif anak salah satunya kemampuan minat baca anak.

Kamus Besar Bahasa Indonesia (KBBI), dalam Sefrina, (2013: 27) Minat berarti kecenderungan hati yang tinggi terhadap sesuatu, diartikan pula sebagai gairah atau keinginan. Dalam bahasa inggris, minat sering digambarkan dengan kata-kata "Interest" atau "Passion". Interest bermakna suatu perasaan ingin memerhatikan dan penggairah atau suatu perasaan yang kuat atau antusiasme terhadap sesuatu objek.

Akhadiah dkk (1993: 22) berpendapat bahwa membaca merupakan suatu kesatuan kegiatan yang mencakup beberapa kegiatan seperti mengenali huruf dan kata-kata, menghubungkan bunyi serta maknanya, serta menarik kesimpulan mengenai maksud bacaan. Membaca sebagai suatu proses untuk memahami makna suatu tulisan. Kemampuan membaca merupakan kemampuan yang komplek menuntut kerjasama antara sejumlah kata. Untuk dapat membaca suatu bacaan, seseorang harus dapat menggunakan pengetahuan yang sudah dimilikinya.Sehingga minat baca anak diartikan kemauan anak untuk mengeja huruf per huruf agar mampu memahami makna kata atau kalimat.

Berdasarkan hasil observasi dan wawancara yang dilakukan peneliti pada tanggal 31 Juli 2015, menunjukan bahwa minat membaca anak pada Kelompok B3/4 TK Darul Fallah Kendari masih sangat rendah yaitu berada pada taraf Mulai Berkembang (MB) atau dengan simbol nilai bintang (**). Hasil penilaian belajar anak yang terdiri dari 4 indikator/aspek penilaian hanya 6 orang anak yang mendapatkan kategori BSH (Berkembang Sesuai Harapan) atau bintang tiga (***) dan BSB (Berkembang Sangat Baik) atau bintang empat (****) atau $35.3 \%$ dari 17 orang anak Hal ini diakibatkan penggunaan media yang tidak tepat dalam merangsang perkembangan minat baca anak, guru masih sangat kaku dalam penyampaian pembelajaran sehingga anak-anak terlihat gaduh dan rebut bahkan anak mengantuk. Kurangnya keterlibatan anak dalam proses pembelajaran mengakibatkan proses pembelajaran yang terlihat membosankan, sehingga peneliti berusaha merancang suatu media yang menarik dan menyenangkan bagi anak untuk meningkatkan minat membaca anak melalui media kartu kata.

Arsyad (2011: 3) mengatakan bahwa media dipahami secara garis besar adalah manusia, materi, atau kejadian yang membangun kondisi yang membuat siswa mampu memperoleh pengetahuan, keterampilan, atau sikap.

Media kartu kata adalah salah satu media kartu yang terbuat dari kertas tebal yang berbentuk persegi panjang yang berisi unsur bahasa terkecil yang dapat diajarkan atau dituliskan. Pengertian kartu kata dalam penulisan ini adalah suatu kartu yang bertuliskan kata-kata yang digunakan sebagai media atau alat dalam proses pembelajaran yang bertujuan untuk meningkatkan kemampuan penguasaan perbendaharaan kata. Diharapkan dalam pembelajaran menggunakan media kartu ini dapat menarik minat baca anak dan anak-anak terlihat senang sebab anak-anak terlibat secara langsung dalam pembelajaran.

\section{METODE}

Jenis penelitian ini adalah penelitian tindakan kelas (PTK). Penelitian tindakan kelas atau sering disebut dengan classroom action research adalah penelitian yang dilakukan oleh guru di kelasnya sendiri melalui refleksi diri dengan tujuan untuk memperbaiki kinerjanya sehingga hasil belajar siswa meningkat. Karakteristik tindakan kelas yaitu tindakantindakan (aksi) yang berulang-ulang untuk memperbaiki proses pembelajaran. Model Kemmis dan Taggart yang meliputi 4 tahap yaitu: rencana tindakan, pelaksanan tindakan, observas, dan refleksi (Aqib, 2011: 3). 
Tempat penelitian di Taman KanakKanak Darul Fallah Wua-wua Kota Kendari. Waktu pelaksanaan penelitian dilaksanakan pada Semester I terhitung bulan Juli- Agustus 2015. Subjek dalam penelitian ini adalah peneliti sebagai guru dan anak kelompok B Taman Kanak-kanak Darul Fallah Wua-wua Kota Kendari yang berjumlah 17 orang terdiri dari 8 orang anak laki-laki dan 9 orang anak perempuan. Adapun dalam penelitian tindakan kelas, peneliti dibantu oleh guru kelas kelompok B3/4 yaitu Hartini Darius, S.Pd., yang bertindak sebagai observer selama penelitian berlangsung.

Faktor-faktor yang diamati peneliti dalam penelitian ini yaitu hasil belajar anak berupa minat membaca anak dan cara guru menggunakan media kartu kartu dalam menarik minat baca anak.

Prosedur pelaksanaan dalam penelitian ini terdiri dari dua siklus dan masing-masing siklus memuat empat (4) kali pertemuan. Desain yang akan digunakan dalam penelitian ini adalah model yang dikemukakan oleh Suharsimi Arikunto dalam Dimyati (2013: 122) bahwa dalam penelitian tindakan kelas ada empat tahap yang dilalui, yakni a) perencanaan, b) pelaksanaan, c) observasi, (d) refleksi.

Teknik pengumpulan data yang digunakan dalam penelitian ini yaitu observasi,wawancara, dan dokumentasi. Teknik penilaian yang digunakan peneliti yaitu dengan menggunakan tanda sebagai berikut: $*=$ Belum Berkembang $(\mathrm{BB})$, ** = Mulai Berkembang (MB), $* * *=$ Berkembang Sesuai Harapan $(\mathrm{BSH})$, dan $* * * *=$ Berkembang Sangat Baik (BSB) (Depdiknas, 2004: 26).

Indikator keberhasilan dalam penelitian ini apabila rencana kegiatan pembelajaran terlaksana minimal $75 \%$ baik secara individual maupun klasikal. Maka pembelajaran berhasil dengan pencapaian nilai Berkembang Sesuai Harapan (BSH) dan Berkembang Sangat Baik (BSB) dengan demikian pelaksanaannya dikatakan berhasil.

\section{HASIL DAN PEMBAHASAN}

Peneliti menyusun Rencana Kegiatan Mingguan (RKM) yang kemudian dijabarkan menjadi Rencana Kegiatan Harian (RKH), didalamnya memuat waktu pelaksanaan kegiatan, indikator, kegiatan pembelajaran, media, dan evaluasi. Penelitian ini sesuai dengan jadwal yang telah disusun sebelumnya, yaitu dilaksanakan sebanyak dua siklus kegiatan pembelajaran, yang masing-masing siklus terdiri dari empat (4) kali pertemuan Pada siklus I terdiri atas perencanaan, pelaksanaan, pengamatan, dan refleksi. 1) perencanaan, dalam perencanaan ini yang akan dipersiapkan adalah membuat rencana kegiatan harian (RKH) , membuat lembar observasi baik untuk guru maupun anak untuk melihat bagaimana kondisi dan proses belajar di Kelompok B TK Darul Fallah Kota Kendari, menyiapkan alat peraga yang dibutuhkan di kelas, mendesain alat evaluasi untuk melihat apakah proses belajar dengan menggunakan media kartu kata dapat meningkatkan minat membaca; 2) pelaksanaan tindakan kegiatan yang dilakukan dalam tahap ini adalah melaksanakan rencana pembelajaran yang telah dibuat; 3) pengamatan atau observasi, pada tahap ini dilaksanakan terhadap pelaksanaan tindakan yaitu berkolaborasi atau bekerjasama dengan salah seorang guru di TK Darul Fallah Kendari; 4) refleksi, hal yang diperoleh pada tahap observasi dikumpulkan serta dianalisis dalam tahap ini kelemahankelemahan atau keterangan-keterangan yang terjadi pada setiap pertemuan dalam suatu siklus yang akan diperbaiki pada pertemuan berikutnya atau pada siklus berikutnya.

Pelaksanaan tindakan Siklus I pertemuan I dengan menggunakan tema binatang dan subtema binatang yang hidup di darat dengan tema spesifik yaitu kelinci. Adapun indikator yang harus dicapai anak didik pada setiap pertemuan yaitu: 1) perhatian anak terfokus pada media kartu kata, 2) anak bersedia untuk melakukan kegiatan membaca kata yang ada pada kartu kata, 3) anak lancar dalam menyebutkan kata yang ada pada media kartu kata, dan 4) anak dapat membaca kata yang ada pada media kartu kata.

Pada pelaksanaan tindakan ini, peneliti melaksanakan skenario pemelajaran pada RKH I (tema: binatang/Kelinci), yaitu sebelum kegiatan pembelajaran dimulai, didahului dengan apel/berbaris didepan kelas yang dipimpin oleh salah satu anak didik dan dituntun oleh guru, setelah barisan anak didik rapi, anak didik menyanyikan beberapa lagu,berdoa masuk kelas kemudian mengucapkan salam dan masuk kelas secara tertib. Selanjutnya, setelah anak didik telah duduk dengan rapi membentuk lingkaran, anak didik bernyanyi setelah bernyanyi anak didik mengucapkan surah-surah pendek AlFatihah, Al-Ikhlash, An-Nas, dan doa kedua orang serta ditutup dengan doa sebelum belajar. Pada kegiatan inti dalam pembelajaran dimulai dengan penjelasan guru terlebih dahulu tentang 
kegiatan yang akan dilakukan pada hari itu. Adapun kegiatan yang akan dilakukan oleh anak adalah membaca kata apa yang ada pada kartu, menuliskan kata k-e-l-i-n-c-i dan mewarnai pola gambar kelinci. Pada kegiatan akhir, guru melakukan tanya jawab tentang kegiatan yang telah dilaksanakan. Guru bertanya kepada setiap anak apa saja yang sudah dipelajari tadi, setelah itu menyanyikan beberapa lagu dan mengucapkan doa pulang. Guru mengadakan refleksi kembali pada pembelajaran minat membaca.

Pelaksanaan tindakan Siklus I pertemuan II dengan menggunakan tema binatang dan subtema binatang yang hidup di darat dengan tema spesifik yaitu ayam. Adapun indikator yang harus dicapai anak didik pada setiap pertemuan yaitu: 1) perhatian anak terfokus pada media kartu kata, 2) anak bersedia untuk melakukan kegiatan membaca kata yang ada pada kartu kata, 3) anak lancar menyebutkan kata yang ada pada media kartu kata, dan 4) anak dapat membaca kata yang ada pada media kartu kata. Pada pelaksanaan tindakan ini, peneliti melaksanakan skenario pembelajaran pada RKH II (Tema: Binatang/kambing), yaitu sebelum kegiatan pembelajaran dimulai, didahului dengan apel/berbaris yang dipimpin oleh salah satu anak didik dituntun oleh guru. Setelah barisan anak didik rapi, anak didik menyanyikan beberapa lagu, kemudian mengucapkan salam dan masuk kelas secara berurutan. Selanjutnya, setelah anak didik telah duduk dengan rapi, anak didik mengucapkan surah Al-Fatihah, An-Nas, Al-Ikhlash, dan doa kedua orangtua serta ditutup denga doa sebelum belajar. Pada kegiatan inti dalam pembelajaran dimulai dengan penjelasan guru terlebih dahulu tentang kegiatan yang akan dilakukan pada hari itu. Adapun kegiatan yang akan dilakukan oleh anak adalah menghubungkan angka dengan banyaknya gambar, menebalkan kata kambing, dan mewarnai pola gambar kambing. Pada kegiatan akhir, guru melakukan tanya jawab tentang kegiatan yang telah dilaksanakan. Guru bertanya kepada setiap anak tentang subtema yang telah diajarkan, setelah itu menyanyikan beberapa lagu dan mengucapkan doa pulang. Guru mengadakan refleksi kembali pada pembelajaran minat membaca anak.

Pelaksanaan tindakan Siklus I pertemuan III dengan menggunakan tema binatang dan subtema binatang yang hidup di darat dengan tema spesifik yaitu Kambing. Adapun indikator yang harus dicapai anak didik pada tiap pertemuan yaitu: 1) perhatian anak terfokus pada media kartu kata, 2) anak bersedia untuk melakukan kegiatan membaca kata yang ada pada kartu kata, 3) anak lancar menyebutkan kata yang ada pada media kartu kata, dan 4) anak dapat membaca kata yang ada pada media kartu kata.

Pada pelaksanaan tindakan ini, peneliti melaksanakan skenario pembelajaran pada RKH III (Tema: Binatang/ayam) yaitu sebelum kegiatan pembelajaran dimulai, didahului dengan apel/berbaris yang dipimpin oleh salah satu anak didik dituntun oleh guru. Setelah barisan anak didik rapi, anak didik menyanyikan beberapa lagu, kemudian mengucapkan salam dan masuk kelas secara berurut sambil mencium tangan ibu guru. Selanjutnya, setelah anak didik telah duduk dengan rapi, anak didik mengucapkan syair doa, surah Al-Fatihah, AnNas, dan Al-Ikhlash serta ditutup dengan doa sebelum belajar. Pada kegiatan inti dalam pembelajaran, dimulai dengan penjelasan guru terlebih dahulu tentang kegiatan yang akan dilakukan pada hari itu. Adapun kegiatan yang akan dilakukan oleh anak adalah mewarnai pola gambar ayam, dan menuliskan kata a-y-a-m. Pada kegiatan akhir, guru melakukan tanya jawab tentang kegiatan yang telah dilaksanakan. Guru bertanya kepada setiap anak tentang huruf yang tercantum pada kata a-y-a-m, setelah itu menyanyikan beberapa lagu dan mengucapkan doa pulang. Guru mengadakan refleksi kembali pada pembelajaran minat membaca anak.

Pelaksanaan tindakan Siklus I pertemuan IV dengan menggunakan tema binatang dan subtema binatang yang hidup di darat dengan tema spesifik yaitu Sapi. Adapun indikator yang harus dicapai anak didik pada tiap pertemuan yaitu: 1) perhatian anak terfokus pada media kartu kata, 2) anak bersedia untuk melakukan kegiatan membaca kata yang ada pada kartu kata, 3) anak lancar menyebutkan kata yang ada pada media kartu kata, dan 4) anak dapat membaca kata yang ada pada media kartu kata. Pada pelaksanaan tindakan ini, peneliti melaksanakan skenario pemelajaran pada RKH IV (Tema: Binatang/Sapi) yaitu sebelum kegiatan pembelajaran dimulai, didahului dengan apel/berbaris yang dipimpin oleh salah satu anak didik dituntun oleh guru. Setelah barisan anak didik rapi, anak didik menyanyikan beberapa lagu, kemudian mengucapkan salam dan masuk kelas secara berurutan. Selanjutnya, setelah anak didik telah duduk dengan rapi, anak didik mengucapkan 
syair doa, surah Al-Fatihah, An-Nas, dan AlIkhlash serta ditutup dengan doa sebelum belajar. Pada kegiatan inti dalam pembelajaran, dimulai dengan penjelasan guru terlebih dahulu tentang kegiatan yang akan dilakukan pada hari itu. Adapun kegiatan yang akan dilakukan oleh anak adalah mewarnai pola gambar sapi, dan menuliskan kata S-A-P-I. Pada kegiatan akhir, guru melakukan tanya jawab tentang kegiatan yang telah dilaksanakan. Guru bertanya kepada setiap anak tentang huruf yang tercantum pada kata S-A-P-I, setelah itu menyanyikan beberapa lagu dan mengucapkan doa pulang. Guru mengadakan refleksi kembali pada pembelajaran minat membaca anak.

Berdasarkan perolehan nilai anak didik dalam kegiatan meningkatkan minat membaca anak melalui media kartu kata pada kelompok B TK Darul Fallah Wua-wua Kota Kendari secara klasikal pada siklus I mencapai tingkat keberhasilan sebesar $64.7 \%$, yang dicapai oleh 11 orang anak didik, dimana 3 orang anak memperoleh nilai bintang empat $(* * * *)$ atau Berkembang Sangat Baik (BSB) dengan persentase $17,6 \%$ dan 8 orang anak memperoleh nilai bintang tiga (***) atau Berkembang Sesuai Harapan (BSH) dengan persentase 47,1\%. Hal ini tentu saja akan dihubungkan dengan indikator kinerja yang ditetapkan yaitu jika anak didik mencapai tingkat perolehan nilai keberhasilan sebesar $75 \%$. Tindakan siklus I yang dilaksanakan hanya mencapai perolehan nilai sebesar 64,7\%, maka dapat dikatakan bahwa penelitian tindakan ini belum terselesaikan dan hal ini akan dilanjutkan pada tahapan siklus selanjutnya yaitu siklus II.

Kegiatan pada siklus II mengacu pada 1) perencanaan, pada tindakan ini peneliti kembali menyiapkan hal-hal yang akan dilakukan dalam kegiatan, seperti: membuat skenario pembelajaran berupa rencana kegiatan harian (RKH) untuk siklus II pada pertemuan ke satu sampai dengan pertemuan ke empat, yang mengacu pada pembelajaran meningkatkan minat membaca anak melalui media kartu kata, menyiapkan media kartu kata, membuat lembar observasi aktivitas guru dan anak selama proses pembelajaran, menyediakan alat evaluasi untuk siklus II. 2) pelaksanaan, pada tahap ini tindakan penelitian dilaksanakan di Kelompok B TK Darul Fallah Kendari, anak telah siap belajar dengan guru yaitu meningkatkan minat membaca anak dengan mennggunakan media kartu kata yang telah dipersiapkan sebelumnya. Setelah perencanaan awal, selanjutnya peneliti yang bekerjasama dengan guru Kelompok B untuk melaksanakan tindakan yang sudah direncanakan. Pada pelaksanaan tindakan, guru melaksanakan skenario pembelajaran sesuai Rencana Kegiatan Harian (RKH) yang sudah dipersiapkan terlebih dahulu. 3) pengamatan atau observasi, observasi dilakukan untuk melihat pelaksanaan pembelajaran dengan meningkatkan minat membaca anak melalui media kartu kata sesuai dengan rencana kegiatan harian yang telah dibuat. Observasi dilakukan oleh guru Kelompok B TK Darul Fallah Kendari yang bertindak sebagai observer terhadap hasil belajar anak berupa minat membaca anak.

Pelaksanaan tindakan Siklus II pertemuan I dilaksanakan dengan menggunakan tema binatang dan subtema binatang yang hidup di udara dengan tema spesifik yaitu Kupu-kupu. Adapun indikator yang harus dicapai anak didik pada setiap pertemuan yaitu: 1) perhatian anak terfokus pada media kartu kata, 2) anak bersedia untuk melakukan kegiatan membaca kata yang ada pada kartu kata, 3) anak lancar menyebutkan kata yang ada pada media kartu kata, dan 4) anak dapat membaca kata yang ada pada media kartu kata. Pada pelaksanaan tindakan ini, peneliti melaksanakan skenario pemelajaran pada RKH I (Tema: Binatang/Kupu-kupu), yaitu sebelum kegiatan pembelajaran dimulai, didahului dengan apel/berbaris yang dipimpin oleh salah satu anak didik dan dituntun oleh guru, setelah barisan anak didik rapi, anak didik menyanyikan beberapa lagu, kemudian mengucapkan salam dan masuk kelas secara tertib. Selanjutnya, setelah anak didik telah duduk dengan rapi, anak didik mengucapkan syair doa, surah Al-Fatihah, An-Nas, dan AlIkhlash) serta ditutup dengan doa sebelum belajar. Pada kegiatan inti dalam pembelajaran dimulai dengan penjelasan guru terlebih dahulu tentang kegiatan yang akan dilakukan pada hari itu. Adapun kegiatan yang akan dilakukan oleh anak adalah menyebutkan warna kupu-kupu, menuliskan kata k-u-p-u-k-u-p-u, mewarnai pola gambar kupu-kupu. Pada kegiatan akhir, guru melakukan tanya jawab tentang kegiatan yang telah dilaksanakan. Guru bertanya kepada setiap anak apa saja yang telah di ajarkan pada hari itu, setelah itu menyanyikan beberapa lagu dan mengucapkan doa pulang. Guru mengadakan refleksi kembali pada pembelajaran minat membaca anak.

\begin{tabular}{lllr}
\multicolumn{2}{c}{ Pelaksanaan } & tindakan & Siklus II \\
pertemuan & II & dilaksanakan & dengan \\
menggunakan & tema & binatang dan & subtema
\end{tabular}


binatang yang hidup di udara dengan tema spesifik yaitu burung. Adapun indikator yang harus dicapai anak didik pada setiap pertemuan yaitu: 1) perhatian anak terfokus pada media kartu kata, 2) anak bersedia untuk melakukan kegiatan membaca kata yang ada pada kartu kata, 3) anak lancar menyebutkan kata yang ada pada media kartu kata, dan 4) anak dapat membaca kata yang ada pada media kartu kata. Pada pelaksanaan tindakan ini, peneliti melaksanakan skenario pembelajaran pada RKH II (Tema: Binatang/Burung), yaitu sebelum kegiatan pembelajaran dimulai, didahului dengan apel/berbaris yang dipimpin oleh salah satu anak didik dituntun oleh guru. Setelah barisan anak didik rapi, anak didik menyanyikan beberapa lagu, kemudian mengucapkan salam dan masuk kelas secara berurut sambil mencium tangan ibu guru. Selanjutnya, setelah anak didik telah duduk dengan rapi, anak didik mengucapkan syair doa, surah Al-Fatihah, AnNas, dan Al-Ikhlash serta ditutup dengan doa sebelum belajar. Pada kegiatan inti dalam pembelajaran dimulai dengan penjelasan guru terlebih dahulu tentang kegiatan yang akan dilakukan pada hari itu. Adapun kegiatan yang akan dilakukan oleh anak adalah menyebutkan nama binatang yang terdapat dalam kartu kata, menulis kata burung dan mewarnai pola gambar burung. Pada kegiatan akhir, guru melakukan tanya jawab tentang kegiatan yang telah dilaksanakan. Guru bertanya kepada setiap anak tentang pelajaran yang dilakukan dalam sehari, setelah itu menyanyikan beberapa lagu dan mengucapkan doa pulang. Guru mengadakan refleksi kembali pada minat membaca anak.

Pelaksanaan tindakan Siklus II pertemuan III dilaksanakan dengan menggunakan tema binatang dan subtema binatang yang hidup di udara dengan tema spesifik yaitu lebah. Adapun indikator yang harus dicapai anak didik pada tiap pertemuan yaitu: 1) perhatian anak terfokus pada media kartu kata, 2) anak bersedia untuk melakukan kegiatan membaca kata yang ada pada kartu kata, 3) anak lancar menyebutkan kata yang ada pada media kartu kata, dan 4) anak dapat membaca kata yang ada pada media kartu kata. Pada pelaksanaan tindakan ini, peneliti melaksanakan skenario pemelajaran pada RKH III (Tema: Binatang/Lebah) yaitu sebelum kegiatan pembelajaran dimulai, didahului dengan apel/berbaris yang dipimpin oleh salah satu anak didik dituntun oleh guru. Setelah barisan anak didik rapi, anak didik menyanyikan beberapa lagu, kemudian mengucapkan salam dan masuk kelas secara berurutan. Selanjutnya, setelah anak didik telah duduk dengan rapi, anak didik mengucapkan syair doa, surah Al-Fatihah, An-Nas, Al-Falaq, dan Al-Ikhlash dan ditutup dengan doa sebelum belajar.

Pada kegiatan inti dalam pembelajaran, dimulai dengan penjelasan guru terlebih dahulu tentang kegiatan yang akan dilakukan pada hari itu. Adapun kegiatan yang akan dilakukan oleh anak adalah mewarnai pola gambar lebah, dan menuliskan kata l-e-b-a-h. Pada kegiatan akhir, guru melakukan tanya jawab tentang kegiatan yang telah dilaksanakan. Guru bertanya kepada setiap anak berapa huruf yang tercantum pada kata l-e-b-a-h setelah itu menyanyikan beberapa lagu, mengucapkan doa kedua orang tua, dan doa pulang. Guru mengadakan refleksi kembali pada pembelajaran minat membaca anak.

Pelaksanaan tindakan Siklus II pertemuan IV dilaksanakan dengan menggunakan tema binatang dan subtema binatang yang hidup di udara dengan tema spesifik yaitu nyamuk. Adapun indikator yang harus dicapai anak didik pada tiap pertemuan yaitu: 1) perhatian anak terfokus pada media kartu kata, 2) anak bersedia untuk melakukan kegiatan membaca kata yang ada pada kartu kata, 3) anak lancar menyebutkan kata yang ada pada media kartu kata, dan 4) anak dapat membaca kata yang ada pada media kartu kata. Pada pelaksanaan tindakan ini, peneliti melaksanakan skenario pemelajaran pada RKH IV (Tema: Binatang/Nyamuk) yaitu sebelum kegiatan pembelajaran dimulai, didahului dengan apel/berbaris yang dipimpin oleh salah satu anak didik dituntun oleh guru. Setelah barisan anak didik rapi, anak didik menyanyikan beberapa lagu, kemudian mengucapkan salam dan masuk kelas secara teratur. Selanjutnya, setelah anak didik telah duduk dengan rapi, anak didik mengucapkan syair doa, surah Al-Fatihah, An-Nas, dan AlIkhlash serta ditutup dengan doa sebelum belajar.

Pada kegiatan inti dalam pembelajaran, dimulai dengan penjelasan guru terlebih dahulu tentang kegiatan yang akan dilakukan pada hari itu. Adapun kegiatan yang akan dilakukan oleh anak adalah mewarnai pola gambar nyamuk, dan menuliskan kata nyamuk. Pada kegiatan akhir, guru melakukan tanya jawab tentang kegiatan yang telah dilaksanakan. Guru bertanya kepada setiap anak tentang huruf yang tercantum pada kata n-y-a-m-u-k, setelah itu menyanyikan beberapa lagu dan mengucapkan doa pulang. 
Guru mengadakan refleksi kembali pada pembelajaran minat membaca anak.

Berdasarkan data hasil perolehan anak didik yang dapat disimpulkan bahwa secara klasikal perolehan anak didik dalam kegiatan meningkatkan minat membaca anak melalui media kartu kata pada kelompok B TK Darul Fallah Wua-wua Kota Kendari mengalami peningkatan, karena tingkat keberhasilan anak didik mencapai $88,2 \%$. Anak didik yang memperoleh nilai bintang $(* * * *)$ atau Berkembang Sangat Baik (BSB) dengan persentase $58,8 \%$ yaitu 10 orang anak didik dari 17 orang anak secara keseluruhan. Nilai bintang (***) atau Berkembang Sesuai Harapan (BSH) dengan persentase $29,4 \%$ yaitu diperoleh 5 orang anak didik dan untuk nilai bintang $(* *)$ atau Mulai Berkembang (MB) dengan persentase $11,8 \%$ yaitu diperoleh 2 orang anak didik. Walaupun masih terdapat anak didik yang memperoleh nilai bintang (**) atau Mulai Berkembang (MB) tetapi dapat dikatakan berhasil bahwa sebagian anak didik dilihat telah mampu menyelesaikan tugas-tugas yang telah ditetapkan sesuai dengan indikator penilaian dalam penelitian ini khususnya dalam pelaksanaan tindakan siklus II. Selain itu, dengan perolehan nilai sebesar $88,2 \%$ tersebut telah dicapai oleh 15 orang anak didik, sehingga secara umum dapat dikatakan bahwa program kegiatan atau rangkaian pelaksanaan pembelajaran dalam meningkatkan minat membaca anak melalui media kartu kata di kelompok B3/4 TK Darul Fallah Wua-wua Kota Kendari telah terselesaikan dan sudah mencapai target peneliti yaitu indikator keberhasilan sebesar $75 \%$.

Meskipun masih ada anak didik yang belum terlihat Mulai Berkembang namun hampir semua anak terlihat senang dan antusias dalam pembelajaran ini, sebab mereka dilibatkan secara langsung dalam pembelajaran. Pada setiap harinya sub tema selalu berubah sehingga mereka makin banyak mengetahui jenis-jenis binatang. Adapun dua orang anak yang belum berkembang diakibatkan kedua anak itu sering datang terlambat, dan masih terlihat sangat manja seakan belum mau berpisah dengan orang tuanya.

\section{KESIMPULAN DAN SARAN}

Berdasarkan hasil penelitian dan pembahasan, maka dapat disimpulkan hasil evaluasi minat membaca anak pada siklus I adalah $64.7 \%$ atau 11 orang yang mendapatkan nilai kategori BSH (Berkembang Sesuai Harapan) atau bintang tiga $(* * * / 3)$ dan BSB (Berkembang Sangat Baik) atau bintang empat $(* * * * / 4)$ dari 17 orang anak. Hasil evaluasi minat membaca anak pada siklus II adalah $88.2 \%$ atau 15 orang yang mendapatkan nilai kategori BSH (Berkembang Sesuai Harapan) atau bintang tiga $(* * * / 3)$ dan BSB (Berkembang Sangat Baik) atau bintang empat $(* * * * / 4)$ dari 17 orang anak. Dengan demikian, minat membaca anak pada Kelompok B Taman Kanak-kanak Darul Fallah Wua-Wua Kota Kendari dapat ditingkatkan melalui media kartu kata.

Berdasarkan kesimpulan yang telah dirumuskan, maka peneliti menyarankan hal-hal sebagai berikut: (1) bagi guru, agar penggunaan media kartu kata dapat menjadi salah satu alternatif pedoman pembelajaran untuk meningkatkan minat membaca anak, dapat memberikan bimbingan dan kasih sayang serta motivasi yang disertai sanjungan agar anak lebih aktif dalam mengikuti proses pembelajaran, (2) Bagi sekolah, diharapkan dapat memperbanyak media pembelajaran untuk menunjang fasilitas pembelajaran yang dibutuhkan oleh guru dan anak agar penggunaan mendia kartu kata dapat bermanfaat untuk tambahan pengalaman dan pedoman dalam mengambil kebijakan di sekolah dalam memberikan bimbingan mengajar kepada guru.

\section{DAFTAR PUSTAKA}

Akhadiah, Sabarti. dkk. 1988. Pembinaan Kemampuan Menulis Bahasa Indonesia. Jakarta: Erlangga.

Aqib, Zainal, dkk. 2011. Penelitian Tindakan Kelas. Bandung: Yrama Widya

Arsyad, Azhar. 2011. Media Pembelajaran. Jakarta: Rajawali Pers.

Depdiknas. 2004. Pedoman Pembelajaran Bidang Pengembngan Kognitif di Taman Kanak-Kanak. Jakarta: Depdiknas

Dimyati, Johni. 2013. Metodologi Penelitian Pendidikan dan Aplikasinya pada Pendidikan Anak Usia Dini (PAUD). Jakarta: Kencana

Sefrina, Andin. 2013. Deteksi Minat Bakat Anak. Yokyakarta: Media Pressindo 